\title{
Beyond Accessibility: The Belonging and Participation of Deaf Subjects in the Art Museum of Rio (MAR)
}

\author{
Vanessa Bartolo Guimarães Pereira ${ }^{1}$, Silvia Borges Corrêa ${ }^{2}$ \& Diego Santos Vieira de Jesus ${ }^{3}$ \\ ${ }^{1}$ Professor and researcher of the Brazilian sign language in the Higher School of Advertising and Marketing in Rio de \\ Janeiro (ESPM-Rio), Brazil \\ ${ }^{2} \mathrm{PhD}$ in Social Sciences from the Rio de Janeiro State University (UERJ), Brazil \\ ${ }^{3} \mathrm{PhD}$ in International Relations from the International Relations Institute, Pontifical Catholic University of Rio de \\ Janeiro (IRI / PUC-Rio), Brazil \\ Correspondence: Diego Santos Vieira de Jesus, R. do Rosário, 90 - Centro, Rio de Janeiro - RJ, 20041-002, Brazil
}

Received: July 29, 2020

doi:10.11114/ijsss.v8i5.4978
Accepted: August 14, $2020 \quad$ Available online: August 20, 2020

URL: https://doi.org/10.11114/ijsss.v8i5.4978

\begin{abstract}
Based on a Gramscian perspective on accessibility and inclusion, this article aims to analyze the actions carried out by the Art Museum of Rio (Museu de Arte do Rio, MAR, in Portuguese) that provide for the participation and belonging of deaf subjects who use the Brazilian Sign Language (Libras) in their institutional space. MAR, one of the newest museums in Rio de Janeiro, planned and implemented in the context of the revitalization process of the city's Port Zone, stands out in the Brazilian museum scene with a management that consolidates actions aimed at guaranteeing deaf people's linguistic rights through Libras.
\end{abstract}

Keywords: belonging, accessibility, museums, deaf culture, rio de Janeiro

\section{Introduction}

The discussion about museum's accessibility policies in Brazil began after the creation of the 2010 National Sectorial Plan for Museums (PNSM, its acronym in Portuguese), which intended to define standards for the museum sector from 2010 to 2020. The PNSM presents accessibility as a transversal theme linked to the "Axis II - Culture, city and citizenship". The document proposes that the museum environment should guarantee universal accessibility practices and establish as a priority guideline the development of specific technical capacities and financial resources so that museums make the necessary adaptations to meet the requirements of accessibility and environmental sustainability. At the same time, the intention was to promote critical awareness among the museums' audience and the community where they operate (Celeste \& Silveira, 2019).

The Decree 8.124 / 2013 defines the duty of public and private museums to develop measures to identify aspects of environmental comfort, circulation, visual identity, expansion possibilities, physical accessibility and graphic language aimed at people with disabilities. The purpose was to create the conditions of reach for the museums' use, for anyone, in a safe and autonomous way. In this sense, accessibility was understood as the possibility of access by all people in the environment to the maximum possible usability (Molenzani \& Rocha, 2017). The 2018 National Policy on Museum Education (PNEM, its acronym in Portuguese) contributes to policies that promote respect for diversity and social participation and appreciate the relationship between society and cultural heritage. It also defines "full accessibility" as the search for overcoming the structural barriers that hinder or prevent access to museums and cultural centres, as well as other obstacles which transcend structural aspects (Brazil, 2018).

Based on a Gramscian perspective on accessibility and inclusion, this work aims to analyze the actions carried out by the Art Museum of Rio (Museu de Arte do Rio, MAR, in Portuguese) that provide for the participation and belonging of deaf subjects who use the Brazilian Sign Language (Libras) in their institutional space. MAR, one of the newest museums in Rio de Janeiro, planned and implemented in the context of the revitalization process of the city's Port Zone, stands out in the Brazilian museum scene with a management that consolidates actions aimed at guaranteeing deaf people's linguistic rights through Libras. 


\section{Theoretical Framework}

Although accessibility is guaranteed by law and must be complied with, this practice is not present in most Brazilian institutions and must extrapolate the physical and structural aspects, which means that it is necessary to develop actions that seek to expand and create measures that enable the exercise of citizenship and value plurality and diversity (Celeste $\&$ Silveira, 2019). To think about the ways in which these changes could be implemented and the involved actors, we propose a Gramscian perspective to promote more than accessibility in Brazilian museums, but the inclusion and integration of people with hearing impairment in these spaces. First, it is necessary to understand their place in society in the light of the development of capitalism. Gramsci (2002) understands the notion of "hegemony" as the need for persuasion and convincing of the masses, as well as the search for consensus by the dominant strata, which aim at moral and intellectual leadership over the governed people. Instead of turning his attention exclusively to the material bases of hegemony, the author enters the sphere of culture to argue that such hegemony presupposes that the interests and trends of the groups over which this hegemony will be exercised are considered (Gramsci, 2002). Hegemony must also be economic, which implies that it needs a material basis. The condition for the reproduction of consent is that the hegemonic system produces results that, to some extent, satisfy the short-term material interests of various social groups, such as people with disabilities. Ideological hegemony can only be maintained if it has a material basis, and the action of the subjects occurs within the limits of objective economic determinations (Przeworski, 1989).

According to Gramsci, capitalist production relations can be maintained under democratic conditions and, consequently, exploitation can be maintained with the consent of the exploited people (Gruppi, 1978). The intellectual and moral direction over the governed people is exercised in the field of ideas and culture, thus manifesting the ability of dominant groups to achieve consensus and form a social basis, while other social groups are socially, politically and culturally subordinated not only by force, but also by ideas. Cultural institutions such as the school, the church, and the media function as private devices of hegemony, whose main purpose is to inculcate passive subordination into the dominated individuals (Sassoon, 1980).

To change this situation, the subordinate individuals could adopt a strategy of "war of position" and reshape social forces to build a new state. Just as the bourgeois intellectuals played a role in establishing and maintaining the hegemony of the bourgeois class, the organic intellectuals of the subaltern classes - such as those who make up the deaf population - should also play a similar role in the creation of a new historical bloc, with the task to organize the intellectual and moral reform that would make it possible to adapt culture to practical action. In the case of our research, it is not only about bringing transformations to the physical spaces of the museums, but about valuing diversity and promoting citizenship. According to this understanding, inclusion advocates valuing differences, solidarity, and the right for everyone to enjoy with quality all aspects of life, such as leisure, culture, work, and education. Despite many advances in Brazilian museums, public policies still need a better regulation to guarantee that these measures are applied and experienced. A greater effort by society is also needed to promote full accessibility in all its aspects. Museums, cultural centres, and educational spaces, in addition to being accessible, must provide communication for all visitors and allow them to use their own senses independently (Celeste \& Silveira, 2019).

\section{Methods}

The methodological path first included a bibliographic research, which focused on the material about creative cities, citizenship, deaf culture, Libras, museums, and accessibility. A document research was also carried out to map the museums in Rio de Janeiro. The data were collected on the website of the Brazilian Institute of Museums (Ibram, its acronym in Portuguese) and the websites of all listed museums. The number of 164 museums in the city of Rio de Janeiro was reached. The information was organized, and a chart was built showing several characteristics of these museums, such as location, theme, year of opening and accessibility aspects. The analysis of the chart showed that only four museums in the city had accessibility for deaf people. However, information on which actions were specifically carried out in museums was not described. Only MAR presented the item "educator with specificity in Libras".

In the qualitative research of this article, a semistructured interview was conducted with José do Nascimento Júnior, a specialist in museology and cultural heritage, who was also the coordinator of National Museum Policy between 2003 and 2013 and the Ibram president from 2009 to 2013. He actively participated in the construction of museum policy in the country. The interview with this specialist was extremely important to define the path of this work and consolidate the choice of MAR as the focus of the investigation.

During data collection for this work from August to December 2019, MAR was identified as the museum that presented varied and significant specific actions aimed exclusively at deaf people and their linguistic rights. The information first appeared in the table created with the 164 museums in Rio de Janeiro and, then, in the lecture entitled "Panorama of accessibility in Libras in museums in Rio de Janeiro: the vision of an educator", at the II Forum on Translation and Interpretation of Libras carried out at UFRJ (the Portuguese acronym for Federal University of Rio de Janeiro), in May 
2019. Thyago Corrêa, who was MAR's project educator, presented the actions developed by the museum, specifically for the deaf community and the guarantee of the linguistic rights of the deaf people. On the occasion, we had the opportunity to bring some questions for the speaker and realized that the work developed by MAR pointed to a direction of building the participation of the deaf community in much more complex way than any other museum in Rio de Janeiro.

The chosen research method was the qualitative case study (Yin, 2005) to analyze the activities developed by MAR that could generate participation and, consequently, the belonging of the deaf community in this public space of the city. The aim was to think about the city from the possibility of insertion, access, and participation of the population in a cultural facility.

In this case study, evidence classified by Yin (2005) from six different sources was used: documents, records in archives, interviews, direct observation, participant observation and physical artifacts. For the author, when these principles are incorporated, the quality of the study is substantially increased.

Therefore, an initial direct observation of the space was carried out, with general notes in a field diary, in addition to some approaches (informal interviews) to the public present at the site. The records of the first two visits helped to build the perception of space and its surroundings.

In an informal conversation with Corrêa, it was possible to define a structure for visits and interviews. The possibility of accessing material and documents was discussed, and a first version of a semistructured interview about the history of participation of the deaf people in MAR was prepared. In this conversation, it was clear that Corrêa would be the most suitable person to be interviewed, since he was the one who accompanied the process of the arrival of the deaf community in MAR from the beginning, in 2015. In addition, he had also presented a final paper as a requirement for his MBA in Cultural Accessibility at UFRJ (Corrêa, 2019).

A direct observation was also made of a group of deaf people and students of the UFRJ Libras course on a guided visit with the deaf educator of museum. In September 2019, the IV MAR Deaf Culture Forum took place. On that day, we conducted participant observation and collected some records with audio and video recording and photographs, in addition to conducting some informal interviews with Libras interpreters and deaf people who have been participating in all editions of the Forum and the actions promoted by the museum.

The collection of documents and archives of the museum, which could contribute to the research, was a step that brought many important elements. The MAR Museological Plan, for example, is fundamental for the construction of the analysis of the museum's guidelines. The minutes of the three Deaf Culture Forums that took place in 2016, 2017 and 2018 were also considered. The deaf community's proposals came out for the actions that would take place in the following year. These documents brought the systematization of the debates, ideas and interests mapped in the Forums by the deaf community itself together with the coordination of MAR's projects.

\section{Results}

\subsection{Museums in Brazil and the City of Rio de Janeiro: Accessibility and Inclusion}

From a social, conceptual, and political point of view, the access to cultural and heritage goods has been going through a process of democratization and restructuring. Some initiatives aim to enable the exercise of citizenship. Some contemplate diversity and lead to the adoption of accessibility in cultural places, such as museums (Cohen et al., 2012). The 2010 PNSM accessibility guidelines indicate that science and technology, image, sound, and military museums should transform into exemplary units in accessibility and environmental sustainability. Art museums should ensure physical, social, informational, and aesthetic accessibility to all types of audiences for art museums, understanding this factor as of importance for socio-environmental sustainability. History museums should ensure effective accessibility measures to museums and museum information, including awareness-raising information on sustainable development and its relationship / integration with the environment for all types of public. In museum archives and libraries, physical and virtual accessibility should be guaranteed and information on national cultural heritage should be disseminated in a sustainable manner with the integration of their archives and bibliographic collections (Brazil, 2010).

Some accessibility actions were prioritized in the 2010 PNSM and other government documents, such as the development of educational programs and actions; the restructuring of the museum spaces to ensure accessibility to society, including renovations, constructions, restorations of movable and immovable property; and the acquisition of equipment and collections, which may create and implement specific rules and procedures for museums and cultural centres to guarantee universal accessibility, according to Brazilian accessibility standards. In addition to the training measures for professionals in the museums, it was necessary to prepare a diagnosis regarding accessibility in an interinstitutional way, which would identify specific needs of each museum unit, seek to establish measures to enable interaction between the public and the museum, comply with the laws regarding accessibility, diversify the means of transport for access and ensure the effective development of actions aimed at promoting accessibility (Celeste \& Silveira, 2019). 
Cohen et al. (2012) argue that the main motivations of the museums are not only their collections, but their relations with the community, territory, and heritage, prioritizing the importance of accessibility in these spaces. As the body that regulates accessibility measures in museums, Ibram has taken these motivations into consideration and included in its annual Action Plans the Accessibility Museums Program to comply with current legislation, promote the interaction of people with disabilities with the physical space of museums and carry out projects, diagnoses, interventions and physical adaptations in the spaces, as well as promote debates, meetings and seminars and produce accessibility materials. The 2018 PNEM and the documents that followed the national policy have shown the late concern of Brazilian authorities with accessibility issues, present in discussions in international organizations since the 1950s. Despite the late concern of authorities, museums and accessibility specialists have shown a growing concern with accessibility initiatives, including the educational ones that must consider the particularity of each visitor (Celeste \& Silveira, 2019).

Tojal (2007) argues that public policies need planned and articulated actions to provide accessibility in an integrated manner, both to museums and professionals with the function of training, monitoring, disseminating and permanently evaluating the accessibility programs, developed in the institutions. The author also emphasizes the need to obtain resources for the implementation of specific public policies, considering the local and specific requirements to each institution and its visiting public. Sarraf (2008) indicates the need to consider the right and desire of people with disabilities to benefit from access to culture, art and cultural heritage, which implies new mediation strategies and access to information. Cardinali (2008) argues that, for a society to be inclusive, it is necessary to search for resources that aim to include and not simply insert the person into the environments destined to their education, health, leisure and work.

Some authors indicate that the content and cultural language are fundamental so that the entire audience, not only the people with disabilities, can develop body awareness in the relationship with cultural heritage, established through new communication and mediation strategies. Silva (2015), for example, aimed to produce a guide on accessibility for blind and deaf people in museums and cultural centres in Rio de Janeiro based on the multimedia resources used in Braille exhibitions and the Brazilian Sign Language. The purpose was to publicize the spaces. Oliveira (2015) aimed to analyse the training of deaf educators who work in Cultural Accessibility Programs in São Paulo's museums. The author argues that inclusion becomes possible through the planning of educational actions and the development of public policies aimed at accessibility in the cultural spaces of the museums so that people with disabilities can feel welcomed.

However, there are still relatively few studies carried out when it comes to accessibility and inclusion in museums. The mentioned authors tried to work with the diversity of educational, social, sensory, and cultural experiences that permeate the exhibitions and the entire space of the museums to promote critical thought and sensitive education. They all recognize that accessibility goes beyond the physical issues and elimination of architectural barriers to people with disabilities, but must include communicational, attitudinal, cognitive, and social elements in a multisensory approach, as Cohen et al. (2012) argue. Nevertheless, it seems necessary to go beyond accessibility to promote the recognition of people with disabilities in the dimension of the wealth they represent to society and not only give them better opportunities to enjoy museums, but include them as citizens in cultural spaces.

Brazil has 3,868 museums registered by Museusbr, an information platform on Brazilian museums linked to Ibram These museums are classified into eight themes: Arts, architecture and linguistics; Anthropology and Archeology; Exact, earth, biological and health sciences; History; Education, sports and leisure; Communication and transportation means; Production of goods and services; Defense and public security (Museusbr, 2020). The information available at the platform allows us to realize that the distribution of these museums across the national territory is quite uneven and reveals the differences among the regions and the states of the federation. The southeastern region, the richest in the country, concentrates most museums. São Paulo, the most economically prosperous state, is the one that concentrates the largest number of museums: 675. The state of Rio de Janeiro has 330 museums, being the fourth state with most museums in the country. Of these 330 museums, 164 are in the city of Rio de Janeiro. The central region of the city, considering downtown and the Port Zone, concentrates 42 museums. Another relevant aspect to understand the population's access possibilities to museums, in addition to location, is accessibility. Of the 164 museums in the city of Rio de Janeiro, only 53 claim to have accessibility, most of which are related to physical accessibility, such as access ramps, handrails on stairs and ramps, elevators, adapted drinking fountains, adapted bathrooms, wheelchairs for visitor use, exclusive parking space for the disabled and tactile signage. Even fewer are the number of museums in Rio that offer facilities and services for people with hearing and visual impairments; there are only 19. In this very restricted universe, a museum in the port region stands out in terms of accessibility issues: MAR, where visitors have at their disposal tactile models or embossed maps, tactile flooring and, what stands out the most, educators with specificity in Libras.

\subsection{Accessibility and Inclusion of the Deaf Community in MAR}

MAR is a cultural facility which belongs to the city of Rio de Janeiro, this being the first municipal museum with a 
management model administered by a social organization (OS, its acronym in Portuguese). Through a management contract with the Municipal Secretary of Culture, from the year the museum opened, 2013, to the present date, it is the Odeon Institute that has been managing MAR. The museum was designed and built by the City of Rio de Janeiro in partnership with the Roberto Marinho Foundation and seeks, among other issues, to promote the appreciation of the city's history.

MAR is located at Mauá Square, in the port region of the city of Rio de Janeiro. The museum is part of a port zone remodeling project, entitled "Porto Maravilha", a plan for urban reorganization that is part of the actions that preceded the megaevents that took place in the city in the early 2010s, such as the 2012 Rio+20 Conference, the 2013 Confederations Cup, the 2014 World Cup and the 2016 Olympic Games.

MAR is made up of two large buildings with very distinct styles. The two buildings, now interconnected, have their own stories. According to the MAR Museological Plan (2012), one of the buildings is the former Dom João VI mansion, with an eclectic style. The other modernist style building dates from the 1940s, housed the Civil Police hospital and, in its attached sunroom, a bus terminal. Currently, the two buildings that make up MAR are connected by a square with a covered walkway, transforming the two buildings into a harmonic ensemble, an aspect that is highlighted in its museum plan (Museu de Arte do Rio, 2012). The former palace of Dom João VI houses the exhibition halls, which, with the free structure of their halls, receive short and long-term exhibitions. In the modernist style building, in addition to the administration and some departments, the Escola do Olhar operates, defined on the official MAR website as "a center of permanent thought and training, geared especially to the practice and reflection based on the relationship between education and art" (Museu de Arte do Rio, 2020). MAR was designed to be a museum that had a school and, at the same time, a school that had a museum, as its museological proposal is "to provide the development of a reference educational program for actions in Brazil and abroad, combining art and education based on the curatorial program that guides the institution" (Museu de Arte do Rio, 2020). The Escola do Olhar is structured around some areas of activity: Participation, Accessibility and Network, Training, Research and Documentation and thus "the Escola do Olhar's mission is to disseminate contemporary cultural and artistic manifestations, whether local, traditional or academic; to promote the encounter among different cultures, languages and communities; to enable access to public cultural heritage and develop spaces for protagonism for different people, institutions and social groups. Its guiding principles are the deepening of the public dimension of art, respect for democratic values, human rights, diversity, equality, and accessibility" (Museu de Arte do Rio, 2020).

In MAR's museological plan (2012), accessibility is a theme that does not appear as a specific item but runs through the entire plan as a transversal topic. It is only on its official website that the museum specifically presents the actions developed that "contemplate the implantation of research groups on accessibility for the development of proposals for visits, projects of special educational materials, training of educators and promotion of integrated actions with families." (Museu de Arte do Rio, 2020). These actions seek to contemplate general conditions of accessibility, with respect to classifications of urban barriers in buildings, transport, communications, and information.

As already pointed out in this article, MAR stands out in the universe of museums in the city for having particular elements in its actions and specific projects for the deaf community, projects that were elaborated and built with the participation and partnership of the deaf community itself, who frequents the museum. Thus, the museum's mission is emphasized, which values and advocates art education with a focus on knowledge and practice. "The aim of MAR is to be an accessible environment in the full sense of the word" (Museu de Arte do Rio, 2020). However, to understand the current stage of the context of accessibility, particularly the participation and belonging of Libras' deaf users, it is necessary to understand the path taken by MAR in this aspect of social inclusion.

In 2015, MAR received the exhibition "Por Contacto", which did not occupy the museum gallery, but its pilotis space. This exhibition is the culmination of a project called FotoLibras, which brought together photographs of deaf artists from Recife, Cabo de Santo Agostinho and Olinda, cities in the Brazilian state of Pernambuco, in the northeastearn region of the country. These artists participated in photography workshops that took place in their cities and the idea was that, after the completion of the workshops, an exhibition with the photographs could tour Brazil, in situations in which, in addition to the exhibition, the students of the workshop were multipliers of the project.

Along with the exhibition, MAR also received three deaf photographers who would mediate the exhibition and a team of interpreters who would be in the museum for as long as the exhibition was on display. This team arrived in Rio de Janeiro two weeks before the beginning of the exhibition to, among other objectives, carry out the training and formation of the museum's team of educators, since the team had not yet experienced an exhibition from the perspective of deaf people and also lacked Libras skills. The artist Márcio Santana Campelo, during this process, became a mediator in the exhibition and participated in a residency program in MAR, including being part of the working groups in the museum. "The presence of a deaf resident educator in the Accessibility working group, and in the educators' collective 
training, brought attention to a more inclusive educational practice. Questions that went unnoticed were exposed to reflection and systematization of the situations addressed, as there were no deaf people in the group until the resident arrived" (Corrêa, 2019, 11).

During the exhibition and Campelo's stay in MAR, the artist raised the need for a sign to represent MAR. This sign is called, in the deaf community, "baptism". The proposal to invite the deaf community to choose the sign was made to the museum's education management. The proposal was accepted, and it was the artist himself who produced the video calling the deaf community to the meeting in MAR. At the end of the event, the assembled group suggested that other meetings with the deaf community should take place at the museum. In an immediate response to this demand, MAR's education management proposed a visit that would include Libras interpreters for the guided tour, and, in this methodology, a deaf person would be invited to mediate a section of a museum exhibition. The proposal would be called "Conversa de Galeria", a project already existing in the museum, which would be mediated by deaf people chosen by the community itself. Thus, the project that would later be called "MAR em Libras" was born. In addition to this project, there was also the proposal of the Deaf Culture Forum and Education, which was carried out and generated a document called "Public Policies". This document was presented to the MAR board and recognized as the set of proposals to be followed by the institution, understood as reflecting the wishes of the deaf community in relation to the museum (Corrêa, 2019).

In an interview for the authors of this article, Corrêa reports that, since then, several actions have been taking place based on the demands of the deaf community, such as the Week on Deaf Culture and Education, the Deaf Culture Forums, training with teachers in Libras, the poetry evening in Libras, the artistic and educational residency of the deaf at the museum and Libras courses for employees, among other proposals. The Deaf Culture and Education Forum was a deliberative space with the objective of creating and putting into practice the actions that would be proposed in the thematic axes and raised during the event.

In 2018, when the III MAR's Deaf Culture Forum took place, one of the demands of the Education Working Group was the hiring of two deaf people who could act as educators in the museum. It was from this demand that a deaf educator and a trainee with hearing impairment, but a Libras user, were hired by MAR. Both started to work directly in the "MAR em Libras" project. In 2019, a sequenced and long-term course entitled "Deaf Culture, Art and Mediation" was held. This course was also a demand that came through the Forum and brought the deaf subjects who participate or participated in "MAR em Libras".

Since 2015, with the arrival of the deaf community in MAR, all the actions have started to emerge from the listening of these people through the Deaf Culture Forums - which have a deliberative character and bring together deaf individuals engaged in a voluntary commission - and generated a feeling of belonging of these deaf individuals in the museum. Deaf people do participate, exercise their citizenship, occupy a public space of great importance in the Rio de Janeiro scenario and assume a leading role in the choice of actions. As for the management of this museum, its function is to seek ways for the implementation of these actions, being, in fact, a choice of management to accept the demands of the deaf community and guide the accessibility of the museum for deaf people based on these demands.

In 2019, by the choice of the museum's education coordinator, the project "Mar em Libras" no longer had external guests, which mediated a specific exhibition previously selected and were chosen by the deaf who attend MAR. The meetings then stopped being monthly and started to take place in the form of a guided tour every Sunday, with a set time. The "Mar em Libras" project became a space for the deaf educators of the museum to operate; they are the ones who every Sunday stay at a meeting point, next to the ticket office, to receive people who want to take the guided tour in Libras.

Considering the trajectory of MAR in relation to the projects carried out and the actions that fostered and allowed the deaf community to access the museum space, it is understood that, in addition to the issue of accessibility, special forms of relationship with the space were promoted there, the relationship between deaf and listeners and the protagonist relationship of deaf subjects. Therefore, it is worth mentioning not only accessibility, but participation and belonging that lead to the exercise of citizenship among members of the deaf community, as well as the experience of the museum's social function.

\section{Discussion}

The museum's social function is described by UNESCO (2015) in three specific items that, in summary, affirm the museum "as having a key role in society and as a factor in promoting social integration and cohesion". Museums are vital public spaces that must address society as a whole and can therefore "play an important role in the development of social bonds and social cohesion, the construction of citizenship and the reflection on collective identities. Museums must be places open to all and committed to physical access and access to culture for all, including vulnerable groups. They can be spaces for reflection and debate on historical, social, cultural, and scientific themes". (UNESCO, 2015, 5). 
It is this social function that is evident in the actions that MAR develops specifically for the deaf people and that allow thinking beyond accessibility, as it is about thinking about the means to provide participation. These actions can be classified according to three categories of accessibility: physical (or space), information and attitudinal. In the first category, physical or space accessibility, there is a screen near the ticket office with information about the museum in Libras and a model of the museum with information in Libras and Braille. The information accessibility is made possible by the content of the MAR web page with Hand Talk and with some videos in Libras, by the existence of a table of exhibitions in Libras, by the Lungo tool, made available by an electronic device provided at the museum box office and which makes the mediation of texts in Libras exhibitions, guided tours in Libras with deaf educators and Libras translators-interpreters (TILS, its acronym in Portuguese), extension course on Deaf Culture, Art and Mediation, and specific activities during MAR's Deaf Pride Week. Regarding attitudinal accessibility, the Libras course and awareness raising for employees, the hiring of deaf educators and TILS interns and the holding of the deliberative Forum with the participation of deaf people, the Deaf Pride Day and the cultural occupation of pilotis space do stand out, as Figure 1 shows.

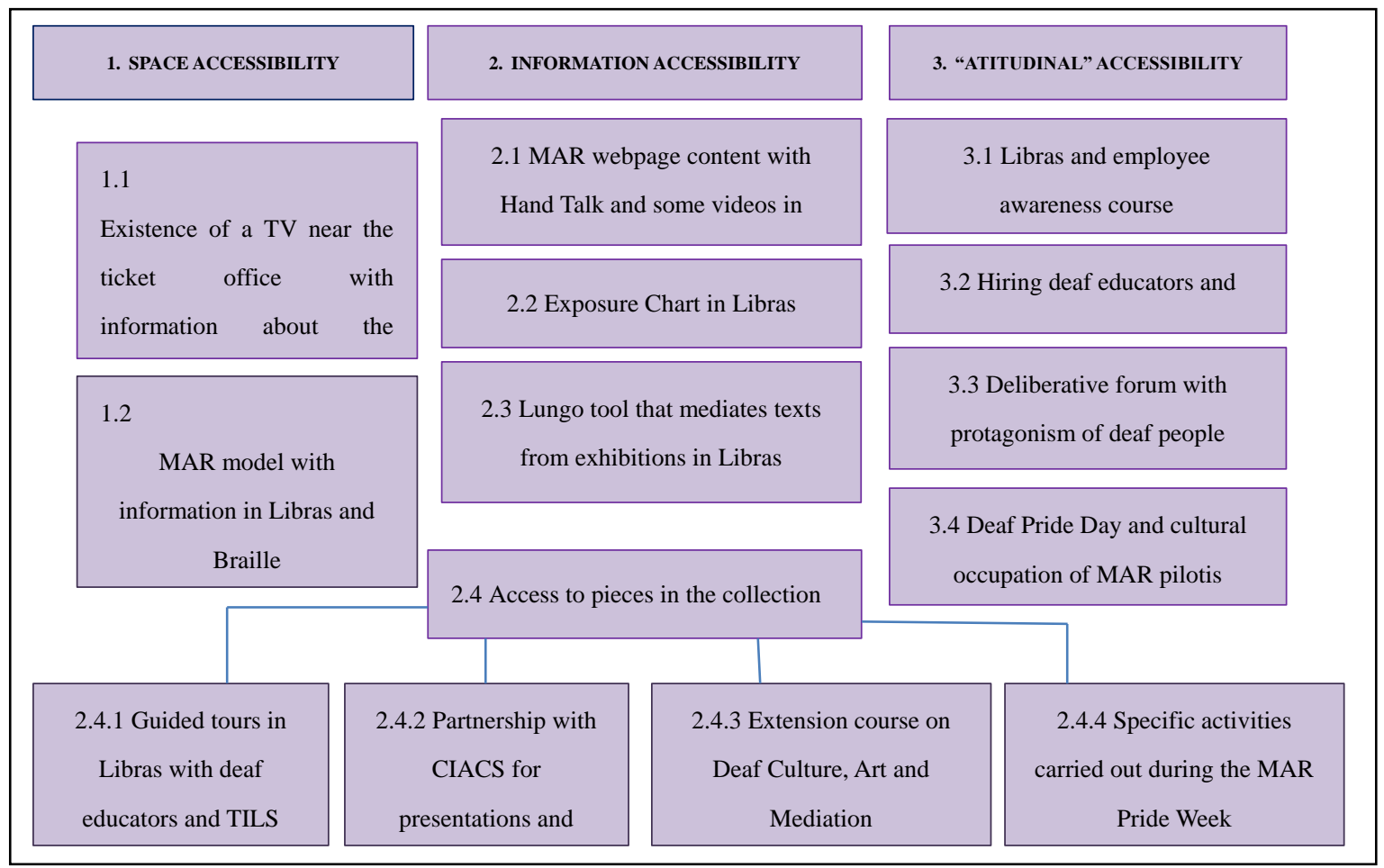

Figure 1 . The actions carried out by MAR in relation to accessibility in museums

MAR has been putting into practice actions that guarantee the accessibility, participation and belonging of deaf users of Libras in a public space in the city, guaranteeing their linguistic right. It has proved to be a space that seeks to implement inclusion policies, where art education is a means of effecting citizenship in which the focus on knowledge and actions collectively is fundamental to consolidate this process.

MAR stands out among other museums in the city of Rio de Janeiro with specific actions for deaf people who use Libras, actions that start from a process of listening to the demands of the deaf people themselves through deliberative forums that take place annually. The deaf actively participate in the actions taken, which generates in these subjects the feeling of belonging that is evidenced, among other moments, in the celebration of an event about the pride of being a deaf person. In a Gramscian perspective, the individuals typically seen as "subaltern" ones - such as those who make up the deaf population - can create a new historical bloc to start the organization of an intellectual and moral reform that would make it possible not only to change the physical space of the museum, but value diversity and promote citizenship. As Celeste \& Silveira (2019) argue, inclusion advocates valuing differences, solidarity, and the right for everyone to enjoy with quality all aspects of life, such as leisure, culture, work, and education.

The choice of MAR made by the deaf themselves, and not another museum in the city, as a space for this celebration signals the importance and success of the actions implemented by the museum over the past few years. Besides, MAR, 
through its management, in addition to complying with laws that oblige Brazilian museums to carry out actions that put into practice concepts of accessibility, chooses to give protagonism to deaf people, placing itself in the position of listening to the demands of these deaf people. It was possible to understand that MAR not only welcomes these subjects, but generates participation in the collective construction and, consequently, the recognition of this museum by the deaf community as a space that generates belonging. It is in this sense that MAR can be thought of as a museum that promotes, in its actions for the public of deaf people, social emancipation, breaks with the hegemonic practice of a museum only as a space of memories, but above all, as a place of law and citizenship, cultural inclusion and resistance, combating all kinds of prejudices and guaranteeing the expression of different voices.

\section{References}

Brazil. (2010). Plano Nacional Setorial de Museus - 2010/2020. Brasília: Ministry of Culture.

Brazil. (2018). Caderno da Política Nacional de Educação Museal. Brasília: Ministry of Culture.

Cardinali, S. M. M. (2008). O Ensino e Aprendizagem da Célula em Modelos Táteis para Alunos Cegos em Espaços de Educação Formal e Não Formal. M.A. Dissertation - Biology. Pontifical Catholic University of Minas Gerais, Minas Gerais.

Celeste, C., \& Silveira, C. (2019). Acessibilidade nos museus brasileiros: tendências da produção acadêmica. Museologia \& Interdisciplinaridade, 8(16), 196-212.

Cohen, R., Duarte, C., \& Brasileiro, A. (Orgs). (2012). Acessibilidade a Museus. Cadernos Museológicos, vol. 2. IBRAM. [WWW page]. Retrieved from http://www.museus.gov.br/wp-content/uploads/2013/07/acessibilidade_a_museu_miolo.pdf

Côrrea, T. B. R. P. (2019). O MAR em Língua Brasileira de Sinais. MBA Final Paper - Cultural Accessibility. Federal University of Rio de Janeiro, Rio de Janeiro.

Gramsci, A. (2002). Cadernos do cárcere. Rio de Janeiro: Civilização Brasileira.

Gruppi, L. (1978). O conceito de hegemonia em Gramsci. Rio de Janeiro: Edições Graal.

Molenzani, A. O., \& Rocha, J. N. (2017). Acessibilidade nos museus e centros de ciências da cidade de São Paulo. Revista do Encontro de Divulgação de Ciência e Cultura, 3(3), 71-83.

Museu de Arte do Rio. (2012). Plano Museológico. Rio de Janeiro: IBRAM.

Museu de Arte do Rio. (2020). O Museu de Arte do Rio de Janeiro. MAR website [WWW page]. Retrieved from http://museudeartedorio.org.br

Museusbr. (2020). Rede Nacional de Identificação de Museus. Museusbr website [WWW page]. Retrieved from http://museus.cultura.gov.br/ .

Oliveira, M. (2015). Cultura e inclusão na educação em museus: processos de formação em mediação para educadores surdos. M.A. Dissertation - Museology. University of São Paulo, São Paulo.

Przeworski, A. (1989). Capitalismo e social-democracia. São Paulo: Companhia das Letras.

Sarraf, V. P. (2008). Reabilitação do museu: políticas de inclusão cultural por meio da acessibilidade. M.A. Dissertation - Culture and Information. University of São Paulo, São Paulo.

Sassoon, A. S. (1980). Gramsci's politics. New York: St. Martin's Press.

Silva, J. P. F. (2015). Acessibilidade aos cegos e surdos nos Museus e Centros Culturais da cidade do Rio de Janeiro. MSc. Dissertation - Diversity and Inclusion. Fluminense Federal University, Niteroi.

Tojal, A. P. F. (2007). Políticas Públicas Culturais de Inclusão de Públicos Especiais em Museus. PhD DissertationInformation Science. University of São Paulo, São Paulo.

UNESCO. (2015). Recomendação referente à proteção e promoção dos museus e coleções, sua diversidade e seu papel na sociedade. UNESCO website [WWW page]. URL https://unesdoc.unesco.org/ark:/48223/pf0000247152.

Yin, R. K. (2005). Estudo de Caso: planejamento e métodos. Porto Alegre: Bookman.

\section{Copyrights}

Copyright for this article is retained by the author(s), with first publication rights granted to the journal.

This is an open-access article distributed under the terms and conditions of the Creative Commons Attribution license which permits unrestricted use, distribution, and reproduction in any medium, provided the original work is properly cited. 